\title{
NUTRITIONAL YIELD AND ECONOMIC RESPONSES OF SUNFLOWER (Helianthus annuus L.) TO INTEGRATED LEVELS OF NITROGEN, SULPHUR AND FARMYARD MANURE
}

\author{
Faisul-ur-Rasool $^{1}$, Badrul Hasan ${ }^{1}$, I.A Jahangir ${ }^{1}$, Tahir Ali ${ }^{1}$ and T. Mubarak ${ }^{1}$
}

\begin{abstract}
The field experiments were conducted at Agronomy Farm of Sher-e-Kashmir University of Agricultural Sciences and Technology of Kashmir during 2009 and 2010, to study the Nutritional yield and economics response of sunflower (Helianthus annuus L.) grown under varying levels of nitrogen, sulphur and farmyard manure. The experiment was laid out in a randomized block design with three nitrogen levels (40, 80 and $120 \mathrm{~kg} / \mathrm{ha}$ ), two sulphur levels (30 and $60 \mathrm{~kg} /$ ha) and three FYM levels (0, 10 and 20 t/ha) having 18 treatment combinations with three replications. The plots were given uniform recommended dose of phosphorus and potassium through diammonium phosphate and muriate of potash at the rate of 60 and $40 \mathrm{~kg} \mathrm{P}_{2} \mathrm{O}_{5}$ and $\mathrm{K}_{2} \mathrm{O} / \mathrm{ha}$, respectively. The soil of the experimental field was silty clay loam in texture, low in available nitrogen and sulphur, high in organic carbon, medium in available phosphorus and potassium with neutral $\mathrm{pH}$. The plant height, leaf area index and dry matter production recorded significant and consistent increase with increase in nitrogen rates from 40 to $120 \mathrm{~kg} /$ ha. Nitrogen rates of 80 and $120 \mathrm{~kg} / \mathrm{ha}$ at par with one another, significantly increased the total number of achenes/capitulum, number of filled achenes/capitulum and 1000-seed weight over $40 \mathrm{~kg} \mathrm{~N} / \mathrm{ha}$. The luxurious seed yield (2.5 tonnes/ha) was recorded with $120 \mathrm{~kg} \mathrm{~N} / \mathrm{ha}$ which remained at par with $80 \mathrm{~kg} \mathrm{~N} / \mathrm{ha} \mathrm{(2.4} \mathrm{t/ha)} \mathrm{and} \mathrm{net} \mathrm{returns} \mathrm{(Rs.} \mathrm{53793),} \mathrm{B:C} \mathrm{(2.1)} \mathrm{ratio} \mathrm{was}$ higher with $120 \mathrm{~kg} \mathrm{~N} / \mathrm{ha}$. Application of $60 \mathrm{~kg} S / \mathrm{ha}$ recorded maximum seed yield (2.42 tonnes/ ha) and net returns (Rs. 49115). Same dose of treatment also recorded higher oil content and oil yield.Application of FYM@10 and 20 t/ha improved seed yield up to the tune of 9 and 15\% over no application, respectively. With net returns of Rs.49093 FYM@10 t/ha proved more profitable. Available nitrogen recorded was highest with treatment combination $120 \mathrm{~kg} \mathrm{~N}+60$ $\mathrm{kg} \mathrm{S}+20 \mathrm{t} \mathrm{FYM/ha}$ and lowest with $40 \mathrm{~kg} \mathrm{N+30} \mathrm{kg} \mathrm{S+0} \mathrm{t} \mathrm{FYM/ha.} \mathrm{Similar} \mathrm{trend} \mathrm{was} \mathrm{observed}$ for available sulphur.
\end{abstract}

Keywords: achene yield, economics, FYM, oil content, nitrogen, sulphur, sunflower

\section{INTRODUCTION}

Oil seeds play an important role in Indian agriculture as food and an industrial commodity. India is the largest producer of oilseeds in the world in terms of output and in terms of area. Among the oilseed crops, sunflower (Helianthus annuus L.), is an all-season crop. In India, it is cultivated over an area of about 2.4 million hectares with a production of 1.44 million tonnes (Anonymous, 2008). To the Kashmir valley, it has been recently introduced, where hardly any oilseed crop is cultivated in kharif (JuneSeptember) season. It is a crop with short duration and photo-insensitivity, suits well to rainy season (Thimmegowda et al., 2007). Nitrogen is the most important limiting nutrient 
required by the plant. It helps in the early growth, better assimilation of carbohydrates and synthesis of proteins. Nitrogen also affects the seed quality by increasing proteins and decreasing oil concentration (Gudade et al., 2009). Sulphur is also increasingly being recognized as the fourth major plant nutrient next to nitrogen, phosphorus and potassium (Tendon and Messick, 2002). It helps in the synthesis of cystein, methionine, chlorophyll, vitamins ( $\mathrm{B}$, biotin and thiamine), metabolism of carbohydrates, increasing oil and protein contents as well as is associated with growth and metabolism, especially affecting the protolytic enzymes (Najar et al., 2011). For higher productivity and sustainability, integrated use of organic and inorganic sources of nutrients is considered to be very important. It is a well established fact that regular integrated use of fertilizer, organic manures and residues in rotation is essential for sustaining moderate to high crop yields, at the same time improving soil organic matter and fertility (Sharma et al., 2008). The chemical fertilizer is supplied along with organic materials, the yield decrement, if any in the initial years can overcome by enhanced mineralization of nutrients from fresh organic materials with wide $\mathrm{C}: \mathrm{N}$ ratios by supplementing with slightly higher fertilizer doses. The strength of the conjunctive use system also lies in its ability to meet the short term as well as the long term nutrient requirements of crop through the fast releasing fertilizer nutrient pool and the slow releasing organic nutrient pool, respectively. Hence, there is need to generate quantifiable information on comparison of response and performance of varying rates of sole organic and inorganic nutrients and their conjunctive use in terms of yield and effect on soil fertility and overall soil quality. Apart from providing both macro and micronutrients, FYM increases the availability of added inorganic nutrients resulting in the positive effect on the photosynthetic surface, thereby improved the yield (Byrareddy et al., 2008) In view of above the present investigation was carried out to study the effect of nitrogen, sulphur and farmyard manure applications on growth and yield of sunflower under temperate conditions.

\section{MATERIALS AND METHODS}

The field experiment was conducted for 2-consecutive rainy (kharif) seasons of 2009 and 2010 at the Research farm, Division of Agronomy, Sher-e-Kashmir University of Agricultural Sciences and Technology of Kashmir situated between $34^{\circ} .05 \varnothing \mathrm{N}$ latitude and $74^{\circ} .89 \notin \mathrm{E}$ longitude at an altitude of 1587 meters above mean sea level. The soil was a silty clay loam having $1.4 \%$ coarse sand $18.2 \%$ fine sand $42.4 \%$ silt and $38 \%$ clay and a $p \mathrm{H}$ of $6.5,0.87 \%$ organic carbon and 271.5 , $14.3,160$ and $15.7 \mathrm{~kg} /$ ha available N, P, K and $\mathrm{S}$, respectively. The precipitation was 177.8 and $249.9 \mathrm{~mm}$ during the cropping seasons of 2009 and 2010, respectively. The experiment was laid out in a factorial randomized block design, having 18 treatment combinations with three replications. The treatments comprised of three nitrogen levels viz. 40, 80 and $120 \mathrm{~kg}$ $\mathrm{N} / \mathrm{ha}$, two sulphur levels viz. 30 and $60 \mathrm{~kg} \mathrm{~S} /$ ha and three FYM treatments viz. 0, 10 and 20 tonnes/ha. The sequence of crops grown in experimental field during past three years is summarized in Table 01. Well decomposed FYM (having C:N ratio of 10-12:1) as per treatment was applied to the respective plots and incorporated. Phosphorus at $60 \mathrm{~kg} \mathrm{P}_{2} \mathrm{O}_{5} / \mathrm{ha}$ and potassium at $40 \mathrm{~kg} \mathrm{~K}_{2} \mathrm{O}$ /ha were uniformly applied to each plot as a basal dose during both years of experimentation. Remaining half dose of nitrogen was applied in two equal splits one each at 30-35 DAS and flowering stage. Nitrogen, phosphorus, potassium and sulphur were applied in form of urea, diammonium phosphate, muriate of potash and calcium sulphate dihydrated $\left(\mathrm{CaSO}_{4} 2 \mathrm{H}_{2} \mathrm{O}\right)$, respectively. After opening of furrows, the overnight soaked seed of sunflower variety of "Morden" was sown on 24 and 25 June in 2009 and 2010 respectively. The crop was 
thinned at 15 DAS to retain one seedling per hill at $45 \mathrm{~cm}$ spacing. Light irrigation was given to the crop towards ending June during both the years. Five random plants were selected from each treatment, excluding the border row, for taking observation on plant height. The leaf area index was recorded using canopy analyzer (Accu PAR Model LP-80). For dry matter, representative plant samples in penultimate rows of each plot were dried in shade followed by oven drying at $60-65^{\circ} \mathrm{C}$ to a constant weight. Observations on yield parameters were recorded from five randomly selected plants of each treatment. Crop was harvested manually on 24 and 26 September in 2009 and 2010, respectively. Yield was recorded from net plots, leaving border and penultimate rows. The oil content in seed was determined with Nuclear Magnetic Resonance Spectroscope (Ne Port Analyser Model MK III A) employing non-destructive method of oil estimation in seed. Available nitrogen was determined by "Alkaline Potassium Permanganate Method" (Subbiah and Asija, 1956) and available sulphur by "Turbidimetric method" (Chesnin and Yien, 1960) and recorded in $\mathrm{kg} / \mathrm{ha}$. Economics was worked out using prevailing market prices of inputs and produce. The data obtained in respect of observation were statistically analyzed by the described by Cochran and Cox (1963). The significance of " $\mathrm{F}$ " and " $\mathrm{t}$ " was tested at 5\% level of significance. The critical difference value was determined when " $F$ ' test was significant.

\section{RESULTS AND DISCUSSION}

\section{Effect on crop growth}

The data on growth parameters and yield attributes as influenced by treatments are presented in Table 02 and it revealed a significant increase in growth parameters of sunflower, viz. plant height, leaf area index and dry matter accumulation along with the increase in nitrogen level from 40 to $120 \mathrm{~kg} /$ ha. Growth with respect to these characters was higher with application of $120 \mathrm{~kg} \mathrm{~N} / \mathrm{ha}$, followed by $80 \mathrm{~kg} \mathrm{~N} / \mathrm{ha}$. Since nitrogen is a major constituent of chlorophyll and proteins and its adequate supply through fertilizer encouraged the photosynthesis, the results indicated a better crop growth. Increase in growth attributes in sunflower due to nitrogen application have been reported by Shah and Khanday (2005) and Sarkar and Mallick (2009). Application of sulphur at 60 $\mathrm{kg} / \mathrm{ha}$ recorded consistent improvement in plant height, leaf area index and dry matter production over $30 \mathrm{~kg} \mathrm{~S} / \mathrm{ha}$. This could be observed to the pivotal role of sulphur in regulating the metabolic and enzymatic processes including photosynthesis and respiration as reported by Sreemannarayana and Raju (1994) and Intodia and Tomar (1997). Farmyard manure (FYM) significantly improved the growth parameters of sunflower. Incorporation of FYM at $20 \mathrm{t} / \mathrm{ha}$ improved the growth parameters over no application. This might be due to improvement in soil physical, chemical and biological properties, provision of plant growth influencing material such as auxin, amino acids and vitamins produced by their decay which promote the plant growth, increased nutrition status due to addition of organic manure and adds the micro-nutrients. These results are in conformity with the findings of Melo and De-Oliveira (1999), Imayavarambani et al., (2002), and Ahmad and Jabeen (2009).

Table 01: Cropping history of the experimental field

\begin{tabular}{llc}
\hline Year & Kharif & Rabi \\
\hline $2007-08$ & Maize & Lentil based intercropping \\
$2008-09$ & Maize & Lentil based intercropping \\
2009 (Kharif) & Sunflower (Experimental) & - \\
2010 (Kharif) & Sunflower (Experimental) & - \\
\hline
\end{tabular}


Table 02: Growth parameters of sunflower as influenced by nitrogen, sulphur and FYM levels (pooled over two years)

\begin{tabular}{lccc}
\hline Treatment & $\begin{array}{c}\text { Plant } \\
\text { height } \\
\text { (cm) }\end{array}$ & $\begin{array}{c}\text { Leaf } \\
\text { Area }\end{array}$ & $\begin{array}{c}\text { Dry } \\
\text { matter }\end{array}$ \\
& & & \\
Index & (t/ha) \\
\hline Nitrogen levels $(\mathrm{kg} /$ & & & \\
ha) & 106.4 & 0.50 & 6.15 \\
40 & 112.0 & 0.82 & 6.89 \\
80 & 115.9 & 0.96 & 7.20 \\
120 & 1.14 & 0.04 & 0.103 \\
SE (m) \pm & 3.31 & 0.11 & 0.298 \\
CD (p=0.05) & & & \\
Sulphur levels $(\mathrm{kg} /$ & & & \\
ha) & 110.24 & 0.68 & 6.59 \\
30 & 112.70 & 0.84 & 7.40 \\
60 & 0.93 & 0.03 & 0.084 \\
SE (m) \pm & 2.7 & 0.09 & 0.243 \\
CD (p=0.05) & & & \\
FYM levels (t/ha) & 108.57 & 0.62 & 6.31 \\
0 & 112.50 & 0.82 & 6.91 \\
10 & 113.38 & 0.84 & 7.01 \\
20 & 1.14 & 0.04 & 0.103 \\
SE (m) \pm & 3.31 & 0.11 & 0.298 \\
CD (p=0.05) & & & \\
\hline
\end{tabular}

\section{Effect on Yield Attributes and Seed Yield}

Yield attributes, notably capitulum diameter, achenes/capitulum and 1000-seed weight increased progressively with increase in nitrogen level up to of $120 \mathrm{~kg} / \mathrm{ha}$. This may be ascribed to the overall improvement in crop vigour and production of sufficient photosynthates owing to higher availability of nitrogen (Awasthi et al., 2011). Nitrogen @ $120 \mathrm{~kg} / \mathrm{ha}$, at par with $80 \mathrm{~kg} \mathrm{~N} / \mathrm{ha}$, recorded maximum seed yield over both the years of experimentation (Table 03). Enhancement in yield on pooled basis was 26 and $20 \%$ with 120 and $80 \mathrm{~kg} \mathrm{~N} / \mathrm{ha}$ over $40 \mathrm{~kg} \mathrm{~N} / \mathrm{ha}$, respectively. The possible reason might be positive response of agronomic characteristics associated with yield to nitrogen. Similar findings were reported by Syed et al., (2006). Sulphur

application significantly influences the yield contributing characters. Application of $60 \mathrm{~kg}$ $\mathrm{S} /$ ha significantly increased the head diameter, filled achenes/capitulum and 1000-seed weight over $30 \mathrm{~kg} \mathrm{~S} / \mathrm{ha}$. Synthesis of proteins at higher sulphur level may have resulted in proper partitioning of photosynthates from source to sink resulting in the improvement in yield contributing characters. Seed yield increased significantly by $7.5 \%$ with $60 \mathrm{~kg} \mathrm{~S} /$ ha over $30 \mathrm{~kg} \mathrm{~S} / \mathrm{ha}$. These results corroborate the findings of Ravi et al., (2008). Significant improvement in yield components and seed yield was observed with application of farmyard manure, which sustained better crop growth, produced better yield attributes and ultimately higher seed yield during both the 
years. Increase in grain yield with 10 and 20 tonnes/ha of farmyard manure was to the tune of 9 and $15 \%$ over no application, respectively. FYM seems to act directly in increasing crop yields either by acceleration of respiratory process by increasing cell permeability by hormone growth action or by combination of all the processes viz., release of nutrients and improving soil physical, chemical and biological properties. The beneficial effect of FYM on sunflower is well documented by Awad and Geeresh (1992), Sathiyavelu et al., (1994), Singh et al., (1996) and Manjunatha et al., (2009).

Table 03: Yield attributes and yields of sunflower as influenced by nitrogen, sulphur and FYM levels

\begin{tabular}{|c|c|c|c|c|c|}
\hline Treatment & $\begin{array}{l}\text { Plant } \\
\text { height } \\
\text { (cm) }\end{array}$ & $\begin{array}{l}\text { Leaf } \\
\text { Area } \\
\text { Index }\end{array}$ & $\begin{array}{c}\text { Dry matter } \\
\text { (t/ha) }\end{array}$ & $\begin{array}{l}\text { Seed } \\
\text { yield } \\
\text { (t/ha) }\end{array}$ & $\begin{array}{l}\text { Stalk } \\
\text { yield } \\
(\mathrm{t} / \mathrm{ha})\end{array}$ \\
\hline \multicolumn{6}{|c|}{$\begin{array}{l}\text { Nitrogen levels (kg/ } \\
\text { ha) }\end{array}$} \\
\hline 40 & 106.4 & 0.50 & 6.15 & 2.03 & 4.21 \\
\hline 80 & 112.0 & 0.82 & 6.89 & 2.43 & 4.78 \\
\hline 120 & 115.9 & 0.96 & 7.20 & 2.55 & 5.20 \\
\hline $\mathrm{SE}(\mathrm{m}) \pm$ & 1.14 & 0.04 & 0.103 & 0.06 & 0.07 \\
\hline $\mathrm{CD}(\mathrm{p}=0.05)$ & 3.31 & 0.11 & 0.298 & 0.18 & 0.21 \\
\hline \multicolumn{6}{|c|}{$\begin{array}{l}\text { Sulphur levels (kg/ } \\
\text { ha) }\end{array}$} \\
\hline 30 & 110.24 & 0.68 & 6.59 & 2.23 & 4.63 \\
\hline 60 & 112.70 & 0.84 & 7.40 & 2.45 & 4.84 \\
\hline $\mathrm{SE}(\mathrm{m}) \pm$ & 0.93 & 0.03 & 0.084 & 0.05 & 0.06 \\
\hline $\mathrm{CD}(\mathrm{p}=0.05)$ & 2.7 & 0.09 & 0.243 & 0.14 & 0.17 \\
\hline \multicolumn{6}{|c|}{ FYM levels (t/ha) } \\
\hline 0 & 108.57 & 0.62 & 6.31 & 2.16 & 4.42 \\
\hline 10 & 112.50 & 0.82 & 6.91 & 2.35 & 4.63 \\
\hline 20 & 113.38 & 0.84 & 7.01 & 2.51 & 5.15 \\
\hline $\mathrm{SE}(\mathrm{m}) \pm$ & 1.14 & 0.04 & 0.103 & 0.63 & 0.07 \\
\hline $\mathrm{CD}(\mathrm{p}=0.05)$ & 3.31 & 0.11 & 0.298 & 0.18 & 0.21 \\
\hline
\end{tabular}




\section{Effect on Oil Content and Oil Yield}

Oil content recorded significant decrease with increase in the levels of nitrogen up to 120 $\mathrm{kg} / \mathrm{ha}$ (Table 04). This might be attributed to increased availability of nitrogen at higher rates of nitrogen application, which resulted in greater accumulation of protein in plants and reduces availability of carbohydrates for polymerization into fatty acids, which in turn lower content of oil in the seed. The oil yield increased significantly and consistently with increase in nitrogen levels up to 120 $\mathrm{kg} / \mathrm{ha}$. These results confirm the findings of Ozer et al., (2004) and Aglave et al., (2009). Application of higher level of sulphur significantly increased the oil content and oil yield. Increase in oil content with $60 \mathrm{~kg} \mathrm{~S} / \mathrm{ha}$ was 3 and $2.4 \%$ over $30 \mathrm{~kg} \mathrm{~S} /$ ha during 2009 and 2010, respectively. Oil yield increased by 13.6 and $10 \%$ with $60 \mathrm{~kg} \mathrm{~S} / \mathrm{ha}$ over $30 \mathrm{~kg} \mathrm{~S} /$ ha during 2009 and 2010, respectively. Oil yield is a function of oil content and seed yield and both the parameters increased with higher sulphur level, thus resulting in a significant increase in oil yield. An increase in oil content and oil yield in sunflower due to sulphur application was also earlier reported by Rani et al., (2009). There was significant increase in oil content and oil yield with increase in FYM application. Application of FYM at 20 tonnes/ha remained at par with FYM at 10 tonnes/ha. Increase in oil yield was 10. 4 and $18.6 \%$ during 2009 and 14.3 and $19 \%$ during 2010 with the application of FYM at 10 and 20 tonnes/ha over no application, respectively. The findings corroborate with those of Helmy and Ramadan (2009).

Table 04: Oil content and oil yield of sunflower as influenced by nitrogen, sulphur and FYM levels

\begin{tabular}{lcccc}
\hline Treatment & \multicolumn{2}{c}{ Oil content } & \multicolumn{2}{c}{ Oil yield } \\
& \multicolumn{2}{c}{ (\%) } & \multicolumn{2}{c}{ (t/ha) } \\
& $\mathbf{2 0 0 9}$ & $\mathbf{2 0 1 0}$ & $\mathbf{2 0 0 9}$ & $\mathbf{2 0 1 0}$ \\
\hline Nitrogen levels $(\mathrm{kg} / \mathrm{ha})$ & & & & \\
40 & 40.83 & 40.96 & 0.83 & 0.82 \\
80 & 40.03 & 40.00 & 0.97 & 0.98 \\
120 & 39.86 & 39.48 & 1.02 & 1.01 \\
SE $(\mathrm{m}) \pm$ & 0.239 & 0.360 & 0.010 & 0.006 \\
CD $(\mathrm{p}=0.05)$ & 0.690 & 1.040 & 0.031 & 0.018 \\
Sulphur levels $(\mathrm{kg} / \mathrm{ha})$ & & & & \\
30 & 39.64 & 39.70 & 0.88 & 0.89 \\
60 & 40.84 & 40.66 & 1.00 & 0.98 \\
SE $(\mathrm{m}) \pm$ & 0.195 & 0.294 & 0.009 & 0.005 \\
CD $(\mathrm{p}=0.05)$ & 0.560 & 0.850 & 0.025 & 0.015 \\
FYM levels $(\mathrm{t} / \mathrm{ha})$ & & & & \\
0 & 39.70 & 39.20 & 0.86 & 0.84 \\
10 & 40.45 & 40.64 & 0.95 & 0.96 \\
20 & 40.57 & 40.70 & 1.02 & 1.00 \\
SE (m) \pm & 0.239 & 0.360 & 0.011 & 0.006 \\
CD $(\mathrm{p}=0.05)$ & $\mathrm{NS}$ & $\mathrm{NS}$ & 0.031 & 0.018 \\
\hline
\end{tabular}




\section{Effect on Available Nutrients in Soil}

The available nitrogen in the soil after crop harvest during 2009 and 2010 was not much affected by various treatments (Table 05). The lowest available nitrogen $(269.00 \mathrm{~kg} /$ ha in 2009 and $270.17 \mathrm{~kg} / \mathrm{ha}$ in 2010) was recorded with treatment combination $40 \mathrm{~kg} \mathrm{~N}$ $+30 \mathrm{~kg} \mathrm{~S} / \mathrm{ha}$ along with $0 \mathrm{t} \mathrm{FYM/ha}$ and the highest $(273.6 \mathrm{~kg} / \mathrm{ha}$ in 2009 and $273.9 \mathrm{~kg} / \mathrm{ha}$ in 2010) was found with combination of 120 $\mathrm{kg} \mathrm{N}+60 \mathrm{~kg} \mathrm{~S} / \mathrm{ha}$ along with $20 \mathrm{t} \mathrm{FYM/ha} \mathrm{as}$ against initial available nitrogen $(271.4 \mathrm{~kg} / \mathrm{ha}$ in 2009 and $271.8 \mathrm{~kg} / \mathrm{ha}$ in 2010). This might be attributed to various losses of nitrogen in the soil i.e. denitrification, volatilization etc. Higher available nitrogen in the soil recorded with treatment combination containing 20 t FYM/ha could be attributed to higher rate of mineralization of organic nitrogen in the soil. A similar trend have also been reported by Thimmegowda et al., (2007). Available sulphur in soil showed a marginal increase with different combinations. The lowest available sulphur $(15.85 \mathrm{~kg} / \mathrm{ha}$ in 2009 and $15.92 \mathrm{~kg} / \mathrm{ha}$ in 2010) was recorded with treatment combination $40 \mathrm{~kg} \mathrm{~N}+30 \mathrm{~kg} \mathrm{~S} /$ ha along with $0 \mathrm{t} \mathrm{FYM} / \mathrm{ha} \mathrm{N}_{1} \mathrm{~S}_{1} \mathrm{~F}_{1}$ and the highest available sulphur (18.72 kg/ha in 2009 and $18.82 \mathrm{~kg} / \mathrm{ha}$ in 2010) was obtained with treatment combination $120 \mathrm{~kg} \mathrm{~N}+60 \mathrm{~kg}$ $\mathrm{S} /$ ha along with $20 \mathrm{t} \mathrm{FYM/ha}$ against initial availability of 15.68 and $15.80 \mathrm{~kg} / \mathrm{ha}$ in 2009 and 2010, respectively.

Table 05: Available nitrogen and sulphur (kg/ha) in soil after crop harvest as affected by different levels of nitrogen, sulphur and FYM

\begin{tabular}{|c|c|c|c|c|c|c|c|}
\hline \multirow[t]{3}{*}{$\begin{array}{l}\text { Treatment } \\
\text { Combina- } \\
\text { tions }\end{array}$} & \multicolumn{3}{|c|}{$\begin{array}{l}\text { Added to crop } \\
\text { (kg/ha) }\end{array}$} & \multicolumn{2}{|c|}{$\begin{array}{l}\text { Uptake by crop } \\
\text { (kg/ha) }\end{array}$} & \multicolumn{2}{|c|}{$\begin{array}{l}\text { Available in soil } \\
\text { after harvest (kg/ } \\
\text { ha) }\end{array}$} \\
\hline & Organic & Inorganic & Inorganic & & & & \\
\hline & \multicolumn{2}{|c|}{ Nitrogen } & Sulphur & Nitrogen & Sulphur & Nitrogen & Sulphur \\
\hline $\mathrm{N}_{40} \mathrm{~S}_{30} \mathrm{~F}_{0}$ & - & 40.00 & 30.00 & 54.84 & 11.38 & 269.75 & 15.92 \\
\hline $\mathrm{N}_{40} \mathrm{~S}_{30} \mathrm{~F}_{10}$ & 50 & 40.00 & 30.00 & 67.34 & 12.47 & 272.60 & 16.32 \\
\hline $\mathrm{N}_{40} \mathrm{~S}_{30} \mathrm{~F}_{20}$ & 100 & 40.00 & 30.00 & 72.66 & 13.14 & 273.70 & 16.75 \\
\hline $\mathrm{N}_{40} \mathrm{~S}_{60} \mathrm{~F}_{0}$ & - & 40.00 & 60.00 & 66.86 & 13.19 & 270.17 & 18.32 \\
\hline $\mathrm{N}_{40} \mathrm{~S}_{60} \mathrm{~F}_{10}$ & 50 & 40.00 & 60.00 & 79.36 & 14.27 & 272.10 & 18.45 \\
\hline $\mathrm{N}_{40} \mathrm{~S}_{60} \mathrm{~F}_{20}$ & 100 & 40.00 & 60.00 & 84.68 & 14.92 & 273.10 & 18.48 \\
\hline $\mathrm{N}_{80} \mathrm{~S}_{30} \mathrm{~F}_{0}$ & - & 80.00 & 30.00 & 72.51 & 12.53 & 269.80 & 16.00 \\
\hline $\mathrm{N}_{80} \mathrm{~S}_{30} \mathrm{~F}_{10}$ & 50 & 80.00 & 30.00 & 85.01 & 13.61 & 271.80 & 16.08 \\
\hline $\mathrm{N}_{80} \mathrm{~S}_{30} \mathrm{~F}_{20}$ & 100 & 80.00 & 30.00 & 90.33 & 14.29 & 272.90 & 16.64 \\
\hline $\mathrm{N}_{80} \mathrm{~S}_{60} \mathrm{~F}_{0}$ & - & 80.00 & 60.00 & 84.53 & 14.35 & 270.20 & 18.55 \\
\hline $\mathrm{N}_{80} \mathrm{~S}_{60} \mathrm{~F}_{10}$ & 50 & 80.00 & 60.00 & 97.03 & 15.42 & 271.90 & 18.64 \\
\hline $\mathrm{N}_{80} \mathrm{~S}_{60} \mathrm{~F}_{20}$ & 100 & 80.00 & 60.00 & 102.3 & 16.10 & 273.10 & 18.67 \\
\hline $\mathrm{N}_{120} \mathrm{~S}_{30} \mathrm{~F}_{0}$ & - & 120.00 & 30.00 & 82.76 & 14.75 & 270.90 & 16.01 \\
\hline $\mathrm{N}_{120} \mathrm{~S}_{30} \mathrm{~F}_{10}$ & 50 & 120.00 & 30.00 & 95.26 & 13.61 & 273.00 & 16.22 \\
\hline $\mathrm{N}_{120} \mathrm{~S}_{30} \mathrm{~F}_{20}$ & 100 & 120.00 & 30.00 & 100.5 & 14.34 & 273.80 & 16.50 \\
\hline $\mathrm{N}_{120} \mathrm{~S}_{60} \mathrm{~F}_{0}$ & - & 120.00 & 60.00 & 94.78 & 14.86 & 271.10 & 18.63 \\
\hline $\mathrm{N}_{120} \mathrm{~S}_{60} \mathrm{~F}_{10}$ & 50 & 120.00 & 60.00 & 107.2 & 15.95 & 273.20 & 18.69 \\
\hline $\mathrm{N}_{120} \mathrm{~S}_{60} \mathrm{~F}_{20}$ & 100 & 120.00 & 60.00 & 112.6 & 16.62 & 273.90 & 18.82 \\
\hline
\end{tabular}

* FYM contains $0.5 \%$ 
Table 06: Economics of sunflower as influenced by nitrogen, sulphur and FYM levels

\begin{tabular}{lccc}
\hline Treatment & $\begin{array}{c}\text { Cost of cultivation } \\
\text { (Rs/ha) }\end{array}$ & $\begin{array}{c}\text { Net returns } \\
\text { (Rs/ha) }\end{array}$ & $\begin{array}{c}\text { B:C } \\
\text { ratio }\end{array}$ \\
\hline Nitrogen levels $(\mathrm{kg} / \mathrm{ha})$ & 24310 & 38365 & 1.6 \\
40 & 24794 & 50498 & 2.0 \\
80 & 25278 & 53797 & 2.1 \\
120 & - & - & - \\
SE $(\mathrm{m}) \pm$ & - & - & - \\
CD $(\mathrm{p}=0.05)$ & & & \\
Sulphur levels $(\mathrm{kg} / \mathrm{ha})$ & 24938 & 44867 & 1.8 \\
30 & 25875 & 49115 & 1.9 \\
60 & - & - & - \\
SE (m) \pm & - & - & - \\
CD (p=0.05) & & & \\
FYM levels $(\mathrm{t} / \mathrm{ha})$ & 19017 & 47983 & 2.5 \\
0 & 24017 & 49093 & 2.0 \\
10 & 29017 & 48208 & 1.7 \\
20 & - & - & - \\
$\mathrm{SE}(\mathrm{m}) \pm$ & - & - & - \\
$\mathrm{CD}(\mathrm{p}=0.05)$ & & & \\
\hline
\end{tabular}

\section{Effect on Economics}

The efficiency of a treatment is finally decided in terms of the economics (benefit cost ratio) of that treatment. Net returns (Rs. 5379/ ha) and $\mathrm{B}$ : $\mathrm{C}$ ratio (2.1) were higher with nitrogen application at $120 \mathrm{~kg} / \mathrm{ha}$ (Table 06 ). Application of $80 \mathrm{~kg} \mathrm{~N} /$ ha with net profit of Rs. 50498 and $\mathrm{B}: \mathrm{C}$ ratio 2.0 remained second in order. sulphur at $60 \mathrm{~kg} / \mathrm{ha}$ recorded higher net returns (Rs. 49115/ha) and B:C ratio (1.9) than $30 \mathrm{~kg} \mathrm{~S} / \mathrm{ha}$. Farmyard manure application also improved monetary returns with net returns of Rs. 49093, FYM at10 tonnes/ha proved more profitable over rest of the treatments. B:C ratio was higher (2.5) when FYM was not applied.

\section{CONCLUSION}

Based on the foregoing results, it can be concluded that highest values of sunflower yield, monetary return, yield quality and its components as well as nutrient uptake and available nutrients in the soil were obtained with the plants supplied with $120 \mathrm{~kg} \mathrm{~N}+60$ $\mathrm{kg} \mathrm{S} \mathrm{ha}{ }^{-1}$ with $20 \mathrm{t} \mathrm{FYM} \mathrm{ha}^{-1}$ However, for maintaining soil health $80 \mathrm{~kg} \mathrm{~N}+60 \mathrm{~kg} \mathrm{~S}+10 \mathrm{t}$ FYM ha ${ }^{-1}$ nutrient dose could be recommended for maximum profit under temperate Kashmir conditions.

\section{ACKNOWLEDGEMENT}

The authors are extremely grateful to SKUAST-K for generous assistance for the said project. 


\section{REFERENCES}

Aglave, B. N., Kalegore, N. K., Chavan, M. H. \& Jagtap, P. K. (2009). Performance of rainfed rabi sunflower under varied cropping sequence and nitrogen levels. Journal of Soils and Crops, 19 (2), 265-68.

Ahmad, R. \& Jabeen, N. (2009). Demonstration of growth improvement in sunflower (Helianthus annuus L.) by the use of organic fertilizers under saline conditions. Pakistan Journal of Botany, 41 (3), 1373-1384

Anonymous 2008. Agricultural statistics at a glance. (2008). Directorate of economics and statistics, Department of Agriculture and Coorperation, Ministry of Agriculture, GOI, New Delhi.

Awad, A. \& Geeresh, M.H.M. (1992). Manure and inorganic fertilizer effect on growth and yield of some sunflower cultivars. Annals of Agricultural Sciences, 30, 127-144.

Awasthi, U. D., Dubey, S. D. \& Shripal, (2011). Effect of nitrogen and moisture conservation practices on yield, uptake, water use efficiency and quality of linseed (Linum usitatissimum). Indian Journal of Agricultural Sciences. 81 (4), 383-85.

Byrareddy, K., Uppar, D.S., Vyakaranahal, B.S., Hiremath, S.M., Hunje, R. \& Nadaf, H.I. (2008). Effect of Integrated Nutrient Management on Sunflower Hybrid (KBSH-I) Seed Production. Karnataka Journal of Agricultural Sciences, 21 (2), 171-175.

Chesnin, L. \& Yien, C.H. (1960). Turbidimetric determination of available sulphates. Soil Science Society of American Proceedings, 15, 149-151.

Cochran, G.C. \& Cox, M.M. (1963). Experimental designs. Asia Publishing House, Bombay, (pp. 293-316).

Gudade, B. A., Thakur, M. R., Ulemale, R. B., Imade, S. R. \& Bodhade, M. S. (2009). Nutrient uptake, soil nutrient status and quality of new sunflower varieties as influenced by fertilizer levels. Journal of Soils and Crops. 19 (2), 355-59.

Helmy, A.M. \& Ramadan, M.F. (2009). Agronomic performance and chemical response of sunflower (Helianthus annuus L.) to some organic nitrogen sources and conventional nitrogen fertilizers under sandy soil conditions. Grasas Y Aceites, Enero-Marzo, 60 (1), 55-67.

Imayavarambani, V., Thanunathan, K., Singaravel, R. \& Manickam, G. (2002). Studies on the influence of integrated nutrient management on growth, yield parameters and seed yield of sesame. Crop Research, 24, 309-313.

Intodia, S.K. \& Tomar, O.P. (1997). Effect of sulphur application on growth and yield of sunflower (Helianthus annuus L.). Indian Journal of Agricultural Science, 67 (1), 46-47.

Manjunatha, G. S., Upperi, S. N., Pujari, B. T., Yeledahalli, N. A. \& Kuligod, V. B. (2009). Effect of farm yard manure treated with jeevamrutha on yield attributes, yield and economics 
of sunflower (Helianthus annuus L.). Karnataka Journal of Agricultural Sciences, 22 (1), 198-99.

Melo, J.P.L. \& De-Oliveira, A.P. (1999). Garlic production as a function of different water levels and bovine manure in soil.Horticultura, Grasileira, 17, 11-15.

Najar, G. R., Singh, S. R., Akthar, F. \& Hakeem , S. A. (2011). Influence of sulphur levels on yield, uptake and quality of soyabean (Glycine max) under temperate conditions of Kashmir valley. Indian Journal of Agricultural Sciences, 81 (4), 340-343

Ozer, H., Polat T. \& Ozturk, E. (2004). Response of irrigated sunflower (Helianthus annuus L.) hybrids to nitrogen fertilization : growth, yield and yield components. Plant Soil Environment, 50 (5), 205-211.

Rani, U. K., Sharma, K. L., Nagasri, K., Srinivas, K., Murthy, T.V., Shankar, G..R.., Korwar, G.R., Sankar, G.K., Madhavi, M. \& Grace, J.K. (2009). Response of sunflower to sources and levels of sulphur under rainfed semi-arid tropical conditions. Communication in Soil Science and Plant Analysis, 40 , 2926-2944.

Ravi, S., Channal, H. T., Hebsur, N. S., Patil, B. N. \& Dharmatti, P. R. (2008). Effect of sulphur, zinc and iron nutrition on growth, yield, nutrient uptake and quality of safflower (Carthamus tinctorius L.). Karnataka Journal of Agricultural Sciences, 21 (3), 382-85.

Sarkar, R. K. \& Mallick, R. B. (2009). Effect of nitrogen, sulphur and foliar spray of nitrate salts on performance of spring sunflower (Helianthus annuus L.). Indian Journal of Agricultural Sciences, 79 (12), 986-90

Sathiyavelu, A., Panneerselvam, R.,Venkatakrishan, A.S., Arunachalam, L. \& Purushothaman, S. (1994). Effect of organic manure and fertilizer on the productivity of sunflower. Indian Journal of Agronomy, 39 , 497-498.

Shah, A. H. \& Khanday, B. A. (2005). Response of sunflower (Helianthus annuus L.) to nitrogen and phosphorus under Kashmir valley conditions. SKUAST Journal of Research, 7, 21418 .

Sharma, K. L., Neelaveni, K., Katyal, J. C., Srinivasa, A., Srinavas, K., Grace, K. J. \& Madhavi, M. (2008). Effect of combined use of organic and inorganic sources of nutrients on sunflower yield, soil fertility and overall soil quality in rainfed alfisols. Communications in Soil Science and Plant Analysis, 39, 1791-1831.

Singh, R., Sharma, R.K. \& Singh, M. (1996). Effect of P, Zn, Fe, $\mathrm{CaCO}_{3}$ and FYM application on yield and quality of sunflower. Annals of Biology. 12, 203-208.

Sreemannarayana, B. \& Raju, A.S. (1994). Effect of source and level of sulphur on yield and sulphur content of plant parts of sunflower. Indian Journal of Agricultural sciences, 64(3), 147-151.

Subbiah, B.V. \& Asija, G. L. (1956). A rapid procedure for the determination of available nitrogen in soil. Current Science, 25, 259-260. 
Syed, T. H., Ganai, M. R., Tahir, A. \& Mir, A. H. (2006). Effect of nitrogen and sulphur fertilization on yield and nutrient uptake by sunflower. Journal of Indian Society of Soil Science, 54 (3), 375-76.

Tendon, H. L. S. \& Messick, D. L. (2002). Practical sulphur guide. The Sulphur Institute, Washington, D. C.

Thimmegowda, M. N., Nanjapa, H. V. \& Ramachandrappa, B. K. (2007). Effect of soil solarization and farmyard manure application on weed control and productivity of sunflower (Helianthus annus)-bell pepper (Capsicum annum) sequence. Indian Journal of Agronomy, 52 (3), 204-207. 